\title{
Integrating Digital Competence in Higher Education Curricula: An Institutional Analysis*
}

\author{
Anna Sánchez-Caballé \\ Universidad Isabel I. Spain. \\ anna.sanchez.caballe@ui1.es \\ Mercè Gisbert-Cervera \\ Universitat Rovira i Virgili. Spain. \\ merce.gisbert@urv.cat \\ Francesc Esteve-Món \\ Universitat Jaume I. Spain. \\ festeve@uji.es
}

Received: $13 / 1 / 2020$

Accepted: 30/9/2020

Published: 29/1/2021

\begin{abstract}
Digital competence is key for students in the 21 st century. The present study analyses the extent to which digital competence has been integrated at a Catalan university with 11,362 undergraduate students. To obtain the data, we: (1) analysed the digital competence content in the curricula of 40 bachelor's degrees; and (2) had the results checked by an 11-expert focus group. We found that the more technical degrees have the most integrated indicators of technological literacy while the other knowledge areas have a higher level of information literacy. Educational institutions therefore need to help students develop this competence which is so necessary for 21 st-century students. This study reports interesting results on the presence of digital competence in the curricula of an entire institution and can be useful for improving the institution as a whole and the curricula.
\end{abstract}

Keywords: digital competence; higher education; curricula; content analysis

Resum. La integració de la competència digital en educació superior: un estudi de cas d'una universitat catalana

La competència digital és un element clau per als alumnes del segle XxI. El present estudi consisteix en l'anàlisi, en una institució d'educació superior, del nivell d'integració de la competència digital en els plans d'estudi d'una universitat espanyola integrada per 11.362 estudiants. Per obtenir les dades es van realitzar: (1) una anàlisi del contingut a partir dels plans d'estudis per competències de la universitat amb els indicadors de la competència digital de 40 títols de grau; una discussió de grup amb 11 experts per validar els resultats

* We are grateful for the funding provided through the project Obser@comdid (ref. RTI2018096815-B-I00) funded by the Spanish Ministry of Economy and Competitiveness, and the projects COMDID1 (2014 ARMIF 0039), COMDID2 (2015 ARMIF 00035) and ACEDIM (2017 ARMIF 00031) funded by the Catalan Government. 
obtinguts en el pas anterior. A partir d'aquí s'observa que les titulacions més tècniques integren més els indicadors propis de l'alfabetització tecnològica. En canvi, les altres àrees de coneixement desenvolupen més els indicadors propis de l'alfabetització informacional. En aquest sentit, les institucions d'educació superior han d'ajudar els alumnes a desenvolupar aquesta competència i, per tant, els resultats obtinguts a partir de l'anàlisi institucional permeten disposar d'una visió global de la institució i poden ser útils per a la millora de la universitat i els plans d'estudi.

Paraules clau: competència digital; educació superior; plans d'estudi; anàlisi de contingut

Resumen. La integración de la competencia digital en educación superior: un estudio de caso de una universidad catalana

La competencia digital es un elemento clave para los alumnos del siglo xxI. El presente estudio consiste en el análisis, en una institución de educación superior, del nivel de integración de la competencia digital en los planes de estudio de una universidad catalana integrada por 11.362 estudiantes. Para obtener los datos se realizaron: (1) un análisis del contenido a partir de los planes de estudios por competencias de la universidad con los indicadores de la competencia digital de 40 títulos de grado; una discusión de grupo con 11 expertos para validar los resultados obtenidos en el paso anterior. A partir de aquí se observa que las titulaciones más técnicas integran más los indicadores propios de la alfabetización tecnológica. En cambio, las otras áreas de conocimiento desarrollan más los propios de la alfabetización informacional. En este sentido, las instituciones de educación superior deben ayudar a los alumnos a desarrollar esta competencia y, por tanto, los resultados obtenidos a partir del análisis institucional ofrecen una visión global de la institución y pueden ser útiles para la mejora de la universidad y los planes de estudio.

Palabras clave: competencia digital; educación superior; planes de estudio; análisis de contenido

\author{
Summary \\ 1. Introduction \\ 5. Discussion \\ 2. Theoretical framework \\ 6. Conclusions \\ 3. Method \\ Bibliographical references
}

4. Results

\title{
1. Introduction
}

The last decade has brought with it the fourth industrial revolution. And like the second one, this revolution has led to people being replaced by machines. Each industrial revolution brings new technological advances that involve structural changes in society and economic systems, and society needs to adapt its actions to the new reality. It is estimated that in five years' time 75 million current jobs will become obsolete (Park, 2019). The same author states that, simultaneously, 133 million new job options will appear that will require digital skills, not just physical and cognitive skills. 
Our society is now a digital one and change is taking place at an international level (Rodríguez-García et al., 2019). The digital revolution that has brought about this situation is the result of the speedy development of technology which has improved access to knowledge and information, as well as its administration and circulation (Fang et al., 2018).

As Ali (2019) stated, the evolution of information and communication technologies (ICT) and their growing complexity requires special attention if they are to be correctly integrated into education. The introduction of ICT means that educational institutions have to be modernized if their enormous potential for transforming training processes and providing students with new learning opportunities is to be harnessed (Katic, 2008). Several studies show that ICT influence education and educational reforms and, if correctly implemented, can improve student performance and educational quality. Currently, technology is an essential requirement for personal and academic development (Ali, 2019).

Furthermore, the globalization of ICT involves generating, managing, and transferring knowledge in new ways. Institutions need to implement new administrative practices and direct and indirect contact options with their users. Universities, which are an essential part of the knowledge society, also need to adapt to the new features. The concept of digital university is the adaption of higher education to this new context. The model includes management, administration, and research services focused on the current reality (Ukwueze, 2011).

In this context of higher education, it is important to highlight the role of two agents: participatory citizens, who can build knowledge, and the university, which has responded to the requirements to adapt to the European Higher Education Area (EHEA). Among other aspects, this involves a change in the learning model. The new model should be focused on the development of skills and the inclusion of digital competence (DC) in the curricula (Larraz, 2013).

In recent years, researchers and organizations have published numerous studies and reports on the topic. For example, Sánchez-Caballé et al. (2019) showed that education students have a self-perception of high DC. Nonetheless, being digitally competent or not is not a binary issue. People cannot be said to be either digitally competent or not because they have a wide spectrum of abilities. Some studies value positively that university students have only a few digital abilities/skills. Vázquez-Cano et al. (2020) consider that young people have some digital abilities that are more developed than others, such as those related to the creation of multimedia content. Regardless of whether students' skills are developed or not, it is clear that, as Fernández-Márquez et al. (2020) state, students are almost forced to use DT in everyday life and often use digital devices. Therefore, they need to be trained. This is a topic that has attracted the interest not only of researchers, but also of governments, among them British Columbia (2013), Ministry of Education of Chile (2013) as part of the Enlaces programme, and (3) Uruguay, with the "Plan Ceibal" (Brechner, 2017). 
Therefore, the extent to which DC is now a part of a university's curricula needs to be known. How are the curricula of bachelor's degrees being adapted? And, finally, who is responsible for the development of DC? To respond to these questions, in this article we carry out a content analysis of the integration of DC in the curricula of degree programmes at the Rovira i Virgili University. The results are then checked by a focus group consisting of university professors and staff from various areas of knowledge.

\section{Theoretical framework}

\subsection{Curricula and competencies in higher education}

On 19 June 1999, 30 ministers of education from various European countries met to sign the Bologna Declaration and initiate the EHEA. The EHEA conceives higher education in terms of mobility, transparency, and the recognition of qualifications by European institutions: the main idea of which is to adapt to the new demands of the labour market. In May 2005, 45 countries met again in Bergen to continue working along the same lines (Pons, 2005).

In the same year, within the framework of the project Definition and Selection of Competencies (DeSeCo), the Organisation for Economic Co-operation and Development (OECD, 2005) presented what are known as key competencies, a list of all the competencies that everyone needs for their personal development and fulfilment.

The work did not end there; it was just the beginning. In the following conferences of ministers responsible for higher education, the concept of competence continued to appear on the agenda. Larraz (2013) made the following summary of the most important events: (1) student-centred learning and learning outcomes were the main themes in London 2007; (2) methodological rethinking that places students at the centre of the learning process was discussed in Leuven 2009; (3) the need for students to acquire knowledge, skills, and competencies was the focus of Budapest-Vienna 2010; and (4) the need to combine specific and cross-disciplinary competencies was discussed in Bucharest 2012.

This new conception and methodological renewal was closely related to a shift in the educational paradigm towards cognitivism and social constructivism. Learning is promoted at a personal level where research, experimentation, and interaction are the main knowledge builders (Larraz, 2013).

To align higher education with these new conceptions, four actions were required: (1) the course offering, structure, and design had to be adapted to needs; (2) the methodology had to be renewed; (3) the careers and training of teaching and research staff had to be rethought; and (4) systems to ensure teaching quality had to be developed (Universitat Rovira i Virgili, 2007). At our university, the Universitat Rovira i Virgili, these actions have been progressively integrated to adapt to the principles of Bologna, subjecting the degrees 
to a model of three types of competence - specific, transversal and core - and to knowing, being, and doing (Cela \& Gisbert, 2010).

\subsection{Digital competence}

ICTs are necessary not only for the renewal of higher education, but also for the key competencies. In fact, DC is one of the most commonly repeated competencies in the models (Gisbert et al., 2016). As the OECD (2018) indicates, this is because today's students will have to apply their knowledge in changing digital contexts and in circumstances that are currently unknown and to do so they need digital training (Erstad, 2010).

Gilster (1997) was one of the first authors to define digital literacy. $\mathrm{He}$ considered it as the ability of a student to access, evaluate, and manage information in a multimodal way. Whether the terminology used is literacy or DC, the definition of these terms depends on the author and the moment. For example, Ferrari (2012) considers that students are digitally literate when they can access, evaluate, and manage information. They can build knowledge from a variety of sources and know how to determine whether they are reliable. Authors such as Bawden (2008) and Nawaz and Kundi (2010) also highlight the importance of creating collaboration and cooperation networks to publish and communicate information using both traditional and current tools. Even so, it should be noted that authors such as Larraz (2013) do not understand literacy and competence to be synonyms: they see DC as a sum of literacies. In any case, as Esteve (2015) and Román and Serrano (2018) indicate, all citizens must have DC to become part of the information and knowledge society. Therefore, organizations such as the UNESCO (2018) encourage governments to work towards creating competent digital citizens, so necessary for 21st-century society.

Various institutions, organizations, and authors have tried to define the concept of DC. Eshet-Alkalai (2004), for instance, proposed a holistic model that brings together four types of literacy: (1) Photo-visual, the art of reading visual representations; (2) Reproduction, the art of creatively recycling existing materials; (3) Branching, hypermedia and nonlinear thinking; (4) Information, the art of scepticism; and (5) Socio-emotional. Subsequently, in 2007 the International Society for Technology in Education (ISTE) proposed a DC framework based on several standards: (1) Creativity and innovation; (2) Communication and collaboration; (3) Search and influx of information; (4) Critical thinking, problem solving, and decision making; (5) Digital citizenship; and (6) Technological concepts and actions. For its part, in 2015 the Mozilla company presented Mozilla Web Literacy, which aims to become a guide for good web citizenship. The standards it establishes are: (1) Reading; (2) Writing; (3) Participation; and (4) the 21st-century set of knowledge, skills, and work habits people need to succeed in today's world.

Of all the frames and DC models, we should mention Digcomp, the model proposed by the Institute for Prospective Technological Studies (IPTS). Dig- 
comp 2.1 (Carretero, Vuorikari \& Punie, 2017) is the updated continuation of Digcomp 2.0 (Vuorikari et al., 2016) and Digcomp (Ferrari, 2012). The model consists of: (1) information and data literacy; (2) communication and collaboration through digital technologies; (3) digital content creation; (4) safety; and (5) problem solving, which goes beyond technical issues.

Recently, in 2019 the UK Department for Education also updated the framework that it had presented in 2018 consisting of (1) communication; (2) information and content management; (3) transactions; (4) problem solving; and (5) online security and legality.

It is clear, then, that there are different points of view about what exactly constitutes DC. The present investigation takes as its reference the analysis of Larraz (2013).

As has been mentioned above, Larraz has a comprehensive vision of DC and conceives it in terms of four literacies: (1) informational (i.e. knowing how to handle information); (2) technological (i.e. being able to manage information digitally in various formats); (3) multimedia (analysing and creating multimedia messages); and (4) communicative (participating, communicating by using a digital identity). In turn, the literacies consist of several indicators. Table 1 shows the indicators for each type of literacy.

Table 1. The four DC literacies

\begin{tabular}{|c|c|c|}
\hline & Literacy & Indicators \\
\hline \multirow{4}{*}{ 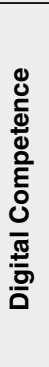 } & Information literacy & $\begin{array}{l}\text { Recognize the need for information } \\
\text { Locate information } \\
\text { Evaluate information } \\
\text { Organize information } \\
\text { Transform information }\end{array}$ \\
\hline & Technological literacy & $\begin{array}{l}\text { Organize and manage hardware and software } \\
\text { Process data in different formats }\end{array}$ \\
\hline & Multimedia literacy & $\begin{array}{l}\text { Understand multimedia messages } \\
\text { Create multimedia messages }\end{array}$ \\
\hline & Communication literacy & $\begin{array}{l}\text { Present and disseminate information } \\
\text { Participate in digital citizenship }\end{array}$ \\
\hline
\end{tabular}

Source: Larraz (2013).

\section{Method}

\subsection{Research questions}

The objective of our content analysis is to determine the extent to which DC has been integrated into the curricula at the Rovira i Virgili University and the potential and shortcomings these curricula have. The present study is descriptive and qualitative, and aims to acquire an in-depth understanding of this reality. The analysis has been performed for 40 bachelor's degrees at the university. 
The research questions (RQ) of the study are:

RQ1: Do the curricula of the Rovira i Virgili University's bachelor's degrees include DC?

RQ2: Which of the four literacies is most implemented?

RQ3: Which knowledge area is best placed in terms of DC?

RQ4: Who is responsible for students developing DC?

\subsection{Context}

The research was carried out in the 2018-2019 academic year at a Catalan university with 11,362 undergraduate students (841 arts and humanities, 859 sciences, 2,650 health sciences, 5,044 social and legal sciences, and 1,968 engineering and architecture) and 3,075 teachers. The university also offers master's degrees and $\mathrm{PhD}$ programmes, and is characterized by the wide range of bachelor's degrees offered and the fact that it has campuses in various towns in the area.

\subsection{Research design}

\subsubsection{Content analysis}

The curricula were reviewed by content analysis, a useful technique for replicating and validating texts, images, and audios (Krippendorff, 2004). As López (2002) indicated, content analysis is used to study and analyze communications in a systematic, objective, quantitative, and descriptive way, and identifies certain specific characteristics of a text so that qualitative conclusions can be drawn (Holsti, 1969).

\subsubsection{Focus group}

According to González et al. (2012), focus groups are a form of qualitative research in which a group of people are asked to express their attitude and opinion about a theme, product, service, or concept.

\subsection{Procedure and analysis design/data analysis}

To obtain the data, we: (1) analysed curriculum content in terms of DC and (2) organized a focus group that checked the results. The workflow is presented in Figure 1.

We began the process by selecting the bachelor's degrees to be reviewed. To do this, we made a list of all the degree options (a total of 61) and then excluded those that were not relevant (degrees in the process of being phased out, double degrees, and those taught by affiliated centres). This reduced the number of degrees from 61 to 40 .

Once the bachelor's degrees had been chosen, we drew up a table to compare the curricula and the DC rubric. A spreadsheet was then prepared for each area of knowledge (social and legal sciences; arts and humanities; 
Figure 1. Revision process of the curricula

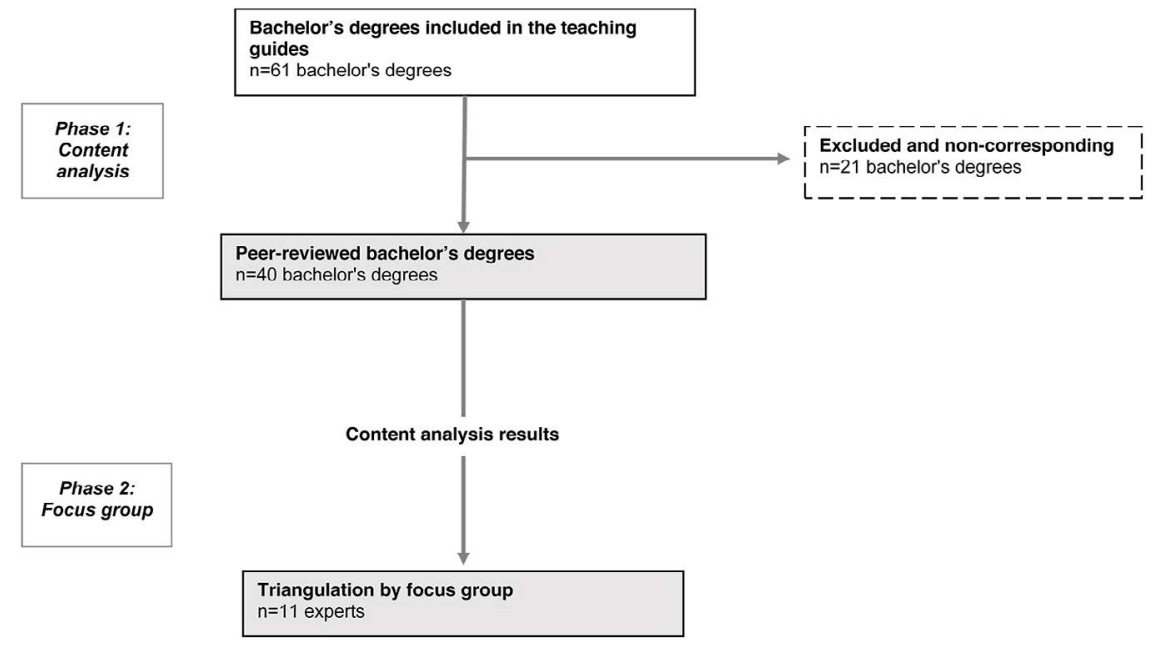

Source: Own elaboration.

architecture and engineering; health sciences; and sciences). On each sheet, the degree competencies are indicated in the rows and the DC indicators in columns.

After the table had been made, the individual researchers began the revision process. As mentioned above, the main selection criterion was the relationship between the competencies and DC reported by Larraz (2013). The next step was the sharing phase, the objective of which was to obtain a peerreviewed proposal to give the analysis more consistency and reliability. The documentation was shared between the two reviewers who had both performed individual analyses. The points on which the curricula and the DC rubric coincided were selected. Any discrepancies were also analysed and discussed. The problem of coding reliability was solved by discussion of the unclear items.

After the results of the curricular analysis had been obtained, they were presented to a focus group of 11 experts for validation. The group of experts was made up of university professors from the various areas of knowledge and university staff involved in academic quality management and ICT integration (Table 2).

The group of experts was asked for three pieces of information: (1) the results from their specific knowledge area, (2) the overall results, and (3) the best option for developing DC. The analysis focused on 55 statements, which were coded in terms of whether the four DC literacies were included in the curricula or not. The coding process also reflects the role of the university in the development of DC. The results of the analysis were presented to the experts. To facilitate the discussion, the items to be discussed were marked in different 
Table 2. Profile of focus group participants

\begin{tabular}{|c|c|c|}
\hline Experts & & $\bar{n}$ \\
\hline \multirow{5}{*}{ 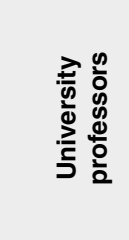 } & Social and Legal Sciences & 2 \\
\hline & Arts and Humanities & 1 \\
\hline & Architecture and Engineering & 1 \\
\hline & Health Sciences & 1 \\
\hline & Sciences & 1 \\
\hline \multirow{5}{*}{ 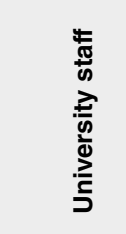 } & Centre for Learning and Research Resources & 1 \\
\hline & Educational Resources Service & 1 \\
\hline & Computer and ICT Service & 1 \\
\hline & Student Office & 1 \\
\hline & Quality Management Office & 1 \\
\hline
\end{tabular}

Source: Own elaboration.

colours. The items given the highest scores were marked in green while the items given the lowest scores were marked in red.

\section{Results}

The results are presented below in two sections. The first shows the specific and general results of the content analysis, while the second lists the information provided by the focus group.

\subsection{Digital competence in the curricula}

The information is shown by the type of literacy, the indicators, and the knowledge area. The data collected by content analysis are presented as absolute percentages which vary depending on the area of knowledge analysed.

Table 3 shows the scores for Information literacy. As can be seen, the organize information indicator shows the highest average score with $13.97 \%$, while the lowest average score was found for the locate information indicator $(10.21 \%)$. In terms of knowledge area, the health sciences show the lowest score, with $4.39 \%$ for the transform information indicator, while social and legal sciences have the highest score, specifically for the organize information indicator $(17.68 \%)$. 
Table 3. Information literacy and knowledge areas

\begin{tabular}{|c|c|c|c|c|c|c|}
\hline \multirow[b]{2}{*}{ Knowledge area } & \multirow[b]{2}{*}{$\begin{array}{c}\text { Competence } \\
\text { number }\end{array}$} & \multicolumn{5}{|c|}{ Information literacy } \\
\hline & & $\begin{array}{l}\text { Recognize } \\
\text { the need for } \\
\text { information }\end{array}$ & $\begin{array}{l}\text { Locate } \\
\text { information }\end{array}$ & $\begin{array}{l}\text { Evaluate } \\
\text { information }\end{array}$ & $\begin{array}{c}\text { Organize } \\
\text { information }\end{array}$ & $\begin{array}{c}\text { Transform } \\
\text { information }\end{array}$ \\
\hline $\begin{array}{l}\text { Architecture and } \\
\text { Engineering }\end{array}$ & 630 & $9.84 \%$ & $10.00 \%$ & $9.20 \%$ & $10.63 \%$ & $8.88 \%$ \\
\hline $\begin{array}{c}\text { Arts and } \\
\text { Humanities }\end{array}$ & 109 & $12.84 \%$ & $12.84 \%$ & $11.00 \%$ & $16.51 \%$ & $11.00 \%$ \\
\hline Health Sciences & 296 & $10.47 \%$ & $6.41 \%$ & $7.43 \%$ & $9.45 \%$ & $4.39 \%$ \\
\hline Sciences & 128 & $12.5 \%$ & $9.37 \%$ & $10.93 \%$ & $15.62 \%$ & $11.71 \%$ \\
\hline $\begin{array}{l}\text { Social and Legal } \\
\text { Sciences }\end{array}$ & 441 & $14.51 \%$ & $12.47 \%$ & $15.87 \%$ & $17.68 \%$ & 15,875 \\
\hline TOTAL & 1604 & $12.03 \%$ & $10.21 \%$ & $10.88 \%$ & $13.97 \%$ & $10.37 \%$ \\
\hline
\end{tabular}

Source: Own elaboration.

Table 4 shows the scores for technological literacy. As can be seen the organize and manage hardware and software indicator shows the highest average score with $9.29 \%$, while the lowest average score was found for the process data in different formats indicator (7.91\%). In terms of knowledge area, architecture and engineering show the highest score for organize and manage hardware and software indicator $(15.85 \%)$, while health sciences show the lowest score for the same indicator $(3.71 \%)$.

Table 4. Technological literacy and knowledge areas

\begin{tabular}{lccc}
\cline { 3 - 3 } \multicolumn{1}{c}{ Knowledge area } & $\begin{array}{c}\text { Competence } \\
\text { number }\end{array}$ & $\begin{array}{c}\text { Organize and } \\
\text { manage hardware } \\
\text { and software }\end{array}$ & $\begin{array}{c}\text { Process data } \\
\text { in different formats }\end{array}$ \\
\cline { 3 - 4 } Architecture and Engineering & 630 & $15.87 \%$ & $8.73 \%$ \\
\hline Arts and Humanities & 109 & $6.42 \%$ & $8.25 \%$ \\
\hline Health Sciences & 296 & $3.71 \%$ & $4.01 \%$ \\
\hline Sciences & 128 & $10.93 \%$ & $8.59 \%$ \\
\hline Social and Legal Sciences & 441 & $9.52 \%$ & $9.97 \%$ \\
\hline TOTAL & 1604 & $\mathbf{9 . 2 9} \%$ & $\mathbf{7 . 9 1 \%}$ \\
\hline
\end{tabular}

Source: Own elaboration.

Table 5 shows the scores for multimedia literacy. As can be observed, the average scores are practically the same, although there is a considerable difference between knowledge areas. For example, the area of health sciences has a score of $3.04 \%$ for the understand multimedia messages indicator and $4.05 \%$ for the create multimedia messages indicator, while social sciences have a score of around $12 \%$ on both indicators. 
Table 5. Multimedia literacy and knowledge areas

\begin{tabular}{lccc}
\cline { 3 - 3 } \multicolumn{1}{c}{ Knowledge area } & $\begin{array}{c}\text { Competence } \\
\text { number }\end{array}$ & $\begin{array}{c}\text { Understand } \\
\text { multimedia } \\
\text { messages }\end{array}$ & $\begin{array}{c}\text { Create multimedia } \\
\text { messages }\end{array}$ \\
\hline Architecture and Engineering & 630 & $8.09 \%$ & $8.09 \%$ \\
\hline Arts and Humanities & 109 & $11.00 \%$ & $11.00 \%$ \\
\hline Health Sciences & 296 & $3.04 \%$ & $4.05 \%$ \\
\hline Sciences & 128 & $8.59 \%$ & $8.59 \%$ \\
\hline Social and Legal Sciences & 441 & $12.24 \%$ & $12.47 \%$ \\
\hline TOTAL & $\mathbf{1 6 0 4}$ & $\mathbf{8 . 5 9 \%}$ & $\mathbf{8 . 8 4 \%}$ \\
\hline
\end{tabular}

Source: Own elaboration.

Lastly, Table 6 shows the scores for communication literacy. As can be seen, the present and disseminate information (11.56\%) and the participate in digital citizenship (11.92\%) indicators show the highest average score. The indicator with the highest score is participate in digital citizenship (14.96\%) in the social and legal sciences knowledge area. Even so, this score is closely matched with the present and disseminate information indicator in the same area. In addition, both indicators in the arts and humanities area also have high scores $(14.67 \%)$. In contrast, health sciences show the lowest scores for both indicators $(7.09 \%)$.

Table 6. Communication literacy and knowledge area

\begin{tabular}{lccc}
\cline { 3 - 3 } \multicolumn{1}{c}{ Knowledge area } & $\begin{array}{c}\text { Competence } \\
\text { number }\end{array}$ & $\begin{array}{l}\text { Present and } \\
\text { disseminate } \\
\text { information }\end{array}$ & $\begin{array}{c}\text { Participate in digital } \\
\text { citizenship }\end{array}$ \\
\hline Architecture and Engineering & 630 & $11.42 \%$ & $12.69 \%$ \\
\hline Arts and Humanities & 109 & $14.67 \%$ & $14.67 \%$ \\
\hline Health Sciences & 296 & $7.09 \%$ & $7.09 \%$ \\
\hline Sciences & 128 & $10.15 \%$ & $10.15 \%$ \\
\hline Social and Legal Sciences & 441 & $14.51 \%$ & $14.96 \%$ \\
\hline TOTAL & 1604 & $\mathbf{1 1 . 5 6 \%}$ & $\mathbf{1 1 . 9 2 \%}$ \\
\hline
\end{tabular}

Source: Own elaboration.

In summary, Figure 2 provides 16 relative scores of the extent to which the four types of literacy have been integrated into the curricula in the five knowledge areas. The number 16 is used as a reference, since it is the next whole 
number after the highest score. On the one hand, it can be seen that social and legal sciences had a greater presence of information, communication, and multimedia literacy in their curricula than technological literacy. On the other hand, in architecture and engineering, technological literacy predominates. The trend in arts and humanities is similar to that of the social sciences: the four literacies are all present similar percentages in the curricula. Science does not have a particularly high level of any of the literacies but the most developed is informational literacy. Finally, as we have seen above, the lowest literacy scores in general are in the area of health sciences.

\subsection{Perspective of university teachers and staff}

Figure 2. Development of literacies by knowledge areas

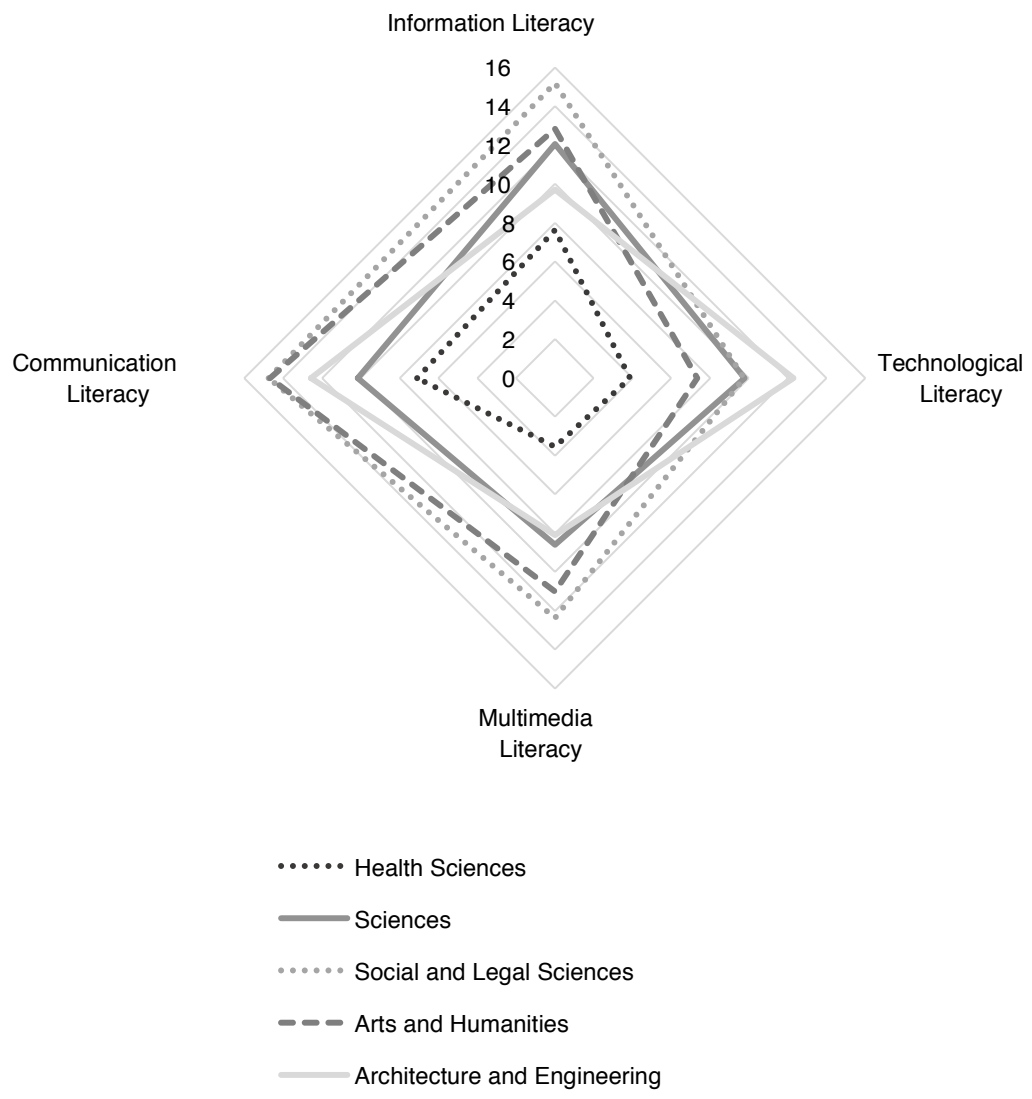

Source: Own elaboration. 
Our curricular analysis shows that information literacy obtains the best scores in most knowledge areas. This is reinforced by the vision of teachers and the administration and services staff, who believe that the university's Centre for Learning and Research Resources (CLRR) works with teachers to train the students (1).

(1) In information literacy [...] what I deduce is that the CLRR does a great job. The CLRR works in conjunction with the degrees.

(2) I am not surprised that in the mechanical engineering degree the information literacy item was marked in red, because this refers to their writing skills. And mechanical engineers are the classic engineers. The main idea is that "an engineer is an engineer" No? So, that's the information, you do not have to look for anything else.

Multimedia literacy is understood by the teaching staff as the ability to make oral presentations and do assignments. Therefore, there is a certain amount of unanimity that students possess these skills even though they are not reflected or taught on the curricula (3 and 4). Some students have an inherent ability in communicative literacy, which is closely related to this point (4).

(3) This one gives me a low score here on multimedia. Our students do presentations and assignments every day. They do these things all day. But they do things that really are not written there...

(4) You should bear in mind that many digital skills or competencies are not on the curricula. Students transfer information by email. They send multimedia messages using WhatsApp. They do Doodles to set meeting dates. There is a lot of DC stuff that is not reflected as a competence in the curricula.

Technological literacy varies according to the knowledge area. It is rated highest in engineering ( 5 and 6 ), and considerably lower in the humanities. According to the teachers, part of the problem is the lack of resources (7).

(5) The "organizing" and managing hardware item is the only one that is green.

(6) Indeed, our item is green.

(7) Humanities have a low score on the item Organize and manage software. I think that this has to do with the availability of equipment.

It is generally regarded that it is difficult to establish who is responsible for developing DC but, even so, the institution should analyse the curricula more often to be aware of the status of the degrees. Another aspect that is given particular emphasis is that university teachers need to be trained to evaluate their students on the basis of their skills and abilities outlined in the curricula (8). There is also a need to continue reinforcing university services such as the 
Factory, 1 which aims to help all members of the university community incorporate IT into their academic activities but has a restricted schedule (9).

(8) But in order to evaluate the portfolio, if the teacher cannot evaluate it, there is no use in the student doing it very well.

(9) I feel like I'm being pessimistic but we always get back to the same issue. CLRR has the Factory ... The CLRR may do a great job with information but in terms of multimedia creation ... there is only one member of staff for the whole university. Do you know what I mean? It all goes back to the lack of resources. But, of course, it would be fine to have more resources and staff.

The qualitative analysis shows that the experts' perception coincides with the results of the content analysis. If we distribute the total scores obtained on the curricula into three equal intervals (with $\leq 4.9 \%$ being low, $5-9.9 \%$ medi$\mathrm{um}$, and $\geq 10 \%$ high), information literacy has a significant presence in all curricula, a fact the experts agree on and attribute to the work done by the CLRR. The integration of multimedia literacy is medium-high and teachers consider this to be due to extra-academic skills. Technological literacy scores the lowest, except in engineering. The experts believe this is due to a lack of resources in non-technical degrees. In all cases, the experts stress the importance of the institution encouraging the development of student DC, and the evaluation of and access to materials. If we focus on knowledge areas, the one that most integrates DC into its study plans is architecture and engineering whereas the one that least integrates it is health sciences.

\section{Discussion}

The objective of this study was to determine the extent to which DC has been integrated into the Rovira i Virgili University curricula. We asked four related questions. The first question was about the extent to which DC is integrated into the curricula of the university.

As mentioned above, the results obtained in the curricula are distributed in three equal intervals (low, medium, and high), which gives us relative values on the level of the four literacies. Firstly, these relative values show that in some areas DC is an intrinsic part of student training. This competence is present in $10-15 \%$ of all the competencies of the degree, which means that it permeates the profile of the university graduate. However, in those cases in which DC or one of its literacies does not reach $5 \%$ of all the competencies of the degree, we understand that the degree does not believe that ICT is of value to future graduates, because its weight in the set of competencies is merely residual.

On the other hand, digital competence is included in the curricula of all degrees. This is because one of the core competencies that all degrees share is DC, as required by the university's initial strategy when it decided to adapt its

1. The Factory is an institutional service that gives support to teaching and research staff and the students to incorporate IT into their academic activities. 
degrees to the EHEA (Cela \& Gisbert, 2010). This means that DC is a core competence and that the conception is closely related to the vision of the European Commission (2018), which considers that DC is a key competence for all citizens regardless of their area of knowledge.

The second question focuses on determining the most common DC literacy in the curricula. In general, it was found that this was information literacy. This was corroborated by the teaching and administrative staff. The CLRR provides the degrees with support for training the students. For their part, teachers also add that students have developed their own daily life skills, which are not reflected in the curricula. These skills are closely related to DC and the various literacies that make it up. Guzmán-Simon et al. (2017) agree with the idea that students have their own informal skills but add that students are not able to integrate them into their work or academic context.

Question three attempts to determine the knowledge area with the highest scores in DC integration. Social and legal sciences is the best positioned in the ranking. This area of knowledge obtained the highest score in all the literacies except technological literacy. Technological literacy obtained the highest score in architecture and engineering, which is quite logical according to Larraz (2013) because it is the most technical literacy and includes both data processing and hardware and software management.

Finally, question four asks who should be responsible for DC development. The focus group shows there is a need to monitor bachelor's degree curricula. Teachers should be given more training in this regard and the university's internal services working on this issue should be reinforced. Fullan (2007) suggested that changes will only come about if learning outcomes are well aligned with the curricula. Thus, acting at the institutional level is as important as implementing particular practices and considering teachers as key to empowering students (Barnett, 2000; Olivares et al., 2018).

\section{Conclusions}

DC is essential for 21st-century students, which is why it must be integrated into university curricula. In the case analysed here, it has been integrated as a core competence. However, more work needs to be done if DC is to be found at all levels and in all areas of knowledge and dimensions. The analysis also shows that the more technical degrees have the most integrated indicators of technological literacy, while the other degrees focus more on information literacy. This is probably due to the type of training and methodology used.

The research provides a snapshot of DC in the curricula of the Rovira i Virgili University. However, future research should go deeper into the issue and take a look at the evidence of learning, which would help to add another vertex to the triangulation process. Along the same lines, one of the following steps would be to analyse students' perception, which would help us continue triangulating. Likewise, for purposes of comparison, it could be enriching to carry out similar projects in other institutions. 
Finally, it is important to point out that this study provides results about DC in the curricula of an entire institution. This information can be used by the institution to improve its curricula and design new formative actions for developing and acquiring DC at university. It may also be useful for students, as well as for teachers and staff. With the proper institutional guidelines, teachers and staff should be able to provide appropriate support to students.

\section{Bibliographical references}

ALI, W. (2019). The efficacy of evolving technology in conceptualizing pedagogy and practice in higher education. Higher Education Studies, 9(2), 81-95.

Barnett, R. (2000). Supercomplexity and the curriculum. Studies in Higher Education, 25(3), 255-265.

Bawden, D. (2008). Origins and concepts of digital literacy. In C. Lankshear \& M. Knobel (eds.). Digital literacies: Concepts, policies and practices (pp. 17-32). New York: Peter Lang.

British Columbia (2013). BC’s Digital Literacy Framework. Retrieved from <https:// www2.gov.bc.ca/assets/gov/education/kindergarten-to-grade-12/teach/teachingtools/digital-literacy-framework.pdfs.

Brechner, M.; Luaces, M.; Moraes, E. \& Borchardt, M. (2017). 10 años de Plan Ceibal. Uruguay: Gerencia de Comunicación de Plan Ceibal

Carretero, S.; Vuorikari, R. \& Punie, Y. (2017). DigComp 2.1: The digital competence framework for citizens. Luxembourg: Publications Office of the European Union.

Cela, J. M. \& Gisbert, M. (2010). La URV hacia el EEES: Proceso de adaptación de las titulaciones de la URV al EEES [The URV towards the EHEA: Process of adapting URV qualifications to the EHEA]. Tarragona: Publicacions URV.

ERSTAD, O. (2010). Educating the digital generation. Nordic Journal of Digital Literacy, 5(01), 56-71.

Eshet-Alkalai, Y. (2004). Digital literacy: A conceptual framework for survival skills in the digital era. Journal of Educational Multimedia and Hypermedia, 13(1), 93.

Esteve, F. (2015). La competencia digital docente Análisis de la autopercepción y evaluación del desempeño de los estudiantes universitarios de educación por medio de un entorno $3 D$ [Digital teaching competence: Analysis of self-perception and performance evaluation of university education students in a $3 \mathrm{D}$ environment] (doctoral dissertation). Universitat Rovira i Virgili, Tarragona.

European Commission (2018). Council Recommendation of 22 May 2018 on key competences for lifelong learning (2018/C 189/01). Official Journal of the European Union.

Fang, M. L.; Canham, S. L.; Battersby, L.; Sixsmith, J.; Wada, M. \& Sixsmith, A. (2018). Exploring privilege in the digital divide: implications for theory, policy, and practice. The Gerontologist, 59(1), 1-15.

Fernández-Márquez, E.; VÁzquez-Cano, E.; López-Meneses, E. \& Sirigiano, F. (2020). La competencia digital del alumnado universitario de diferentes universidades europeas [The digital competence of university students from different European universities]. Espacios, 41, 1-15.

FERRARI, A. (2012). Digital competence in practice: An analysis of frameworks. Sevilla: European Commission, Joint Research Centre (JRC). 
Fullan, M. (2007). The new meaning of educational change. New York: Teachers College.

Gilster, P. (1997). Digital literacy. New York: Wiley Computer.

González, N.; Sedeño, A. \& Gonzálvez, V. (2012). Diseño de un focus group para valorar la competencia mediática en escenarios familiares [Design of a focus group to assess media competence in family settings]. ICONO 14, Revista de comunicación y tecnologías emergentes, 10(3), 116-133.

GuZmán-Simón, F.; García-Jiménez, E. \& López-Сobo, I. (2017). Undergraduate students' perspectives on digital competence and academic literacy in a Spanish University. Computers in Human Behavior, 74, 196-204. $<$ https://doi.org/10.1016/j.chb.2017.04.040>

Holsti, O. (1969). Content analysis for the social sciences and humanities. Reading, MA: Editorial Addison Wesley.

Katic, E. (2008). Preservice teachers' conceptions about computers: An ongoing search for transformative appropriations of modern technologies. Teachers and Teaching, 14(2), 157-179. <https://doi.org/10.1080/13540600801983344>

KRIPPENDORFF, K. (2004). Content analysis: An introduction to its methodology. United States of America: Sage.

LARRAZ, V. (2013). La competència digital a la universitat [Digital competence in the university] (doctoral dissertation). Universitat d'Andorra, Sant Julià de Lòria.

López, F. (2002). El análisis de contenido como método de investigación [Content analysis as a research method]. XXI Revista de Educación, 4, 167-179.

Ministry of Education of Chile (2013). Resultados SIMCE TD 2013 [SIMCE TD results 2013], Enlaces. Retrieved from <http://www.enlaces.cl/wp-content/ uploads/informe-resultados-final-16-12-2014.pdf>.

NawaZ, A. \& Kundi, G. M. (2010). From objectivism to social constructivism: The impacts of information and communication technologies (ICTs) on higher education. International Journal of Science and Technology Education Research, 1(2), 30-36.

OECD (2005). La definición y selección de competencias clave. Resumen ejecutivo [The definition and selection of key competencies. Executive summary]. Organización para la Cooperación y el Desarrollo Económico.

- (2018) The future of education and skills: Education 2030. France: Directorate for Education and Skills-OECD.

Olivares, K. M.; Angulo, J.; Prieto, M. E. \& Torres, C. A. (2018). EDUCATIC: implementación de una estrategia tecnoeducativa para la formación de la competencia digital universitaria [EDUCATIC: implementation of a techno-educational strategy for the formation of digital university competence]. Pixel-Bit: Revista de Medios y Educación, 53, 27-40.

PARK, Y. (2019). DQ Global Standards Report 2019: Common Framework for Digital Literacy, Skills and Readiness. DQ Institute.

Pons, J. P. (2005). El espacio europeo de educación superior. Un reto para la Universidad [The European Higher Education Area. A challenge for the University]. Revista Fuentes, 6.

Rodríguez-García, A. M.; Sánchez, F. R. \& Ruiz-Palmero, J. (2019). Competencia digital, educación superior y formación del profesorado: un estudio de metaanálisis en la web of science [Digital literacy, higher education and teacher training: a meta-analysis study on the web of science]. Pixel-Bit. Revista de Medios y Educación, (54), 65-82. 
Román, M. \& Serrano, J.L. (2018). Ciudadanía digital como marco para el posicionamiento critico ante los cambios de la sociedad [Digital citizenship as a framework for critical positioning in the face of changes in society]. Paper presented at the XXVI Jornadas de Tecnología Educativa, Universidad del País Vasco, San Sebastián.

Sánchez-Caballé, A.; Gisbert-Cervera, M. \& Esteve-Mon, F. (2019). La competencia digital de los estudiantes universitarios de primer curso de grado [The digital competence of first-year university students]. INNOEDUCA. International Journal of Technology and Educational Innovation, 5(2), 104-113.

UK Department for Education (2018). Essential digital skills framework. UK: Crown Copyright.

- (2019). Essential digital skills framework, Updated. UK: Crown Copyright.

UKwUeZE, F. N. (2011). Influence of home media technologies on academic performance of undergraduates. Journal of Home Economics Research, 14, 255-262.

UNESCO (2018). A global framework of reference on digital literacy skills for indicator 4.4.2. Canada: UNESCO Institute for Statistics.

Universitat Rovira i Virgili (2007). La URV davant de l'espai europeu d'educació Superior [The URV in the European Higher Education Area]. Tarragona: Publicacions URV.

Vázquez-Cano, E.; León-Urrutia, M.; Parra-González, M. \& López-Meneses, E. (2020). Analysis of interpersonal competences in the use of ICT in the Spanish University Context. Sustainability, 12(2), 476.

Vuorikari, R.; Punie, Y.; Carretero, S. \& Van den Brande, L. (2016). DigComp 2.0: The digital competence framework for citizens. Update phase 1: The conceptual reference model. Luxembourg: European Commission. 